\title{
A INEFICÁCIA DO CARÁTER PEDAGÓGICO DAS CONDENAÇÕES POR DANOS MORAIS CONTRA AS OPERADORAS DE TELEFONIA MÓVEL EM MACAPÁ/AP
}

\section{Isaac Braga da Silva}

Advogado. Pós-Graduando em Direito Público (Faculdade Estácio do Amapá - Macapá/ AP). E-mail: <isaaclj1@gmail.com>.

\section{Dacicleide Sousa Cunha Gatinho}

Advogada. Mestre em Biodiversidade Tropical (UNIFAP - Universidade Federal do Amapá, Campus Marco Zero, Macapá/AP). Docente da Faculdade Estácio de Macapá.

Resumo: O presente trabalho trata do estudo da aplicação do instituto da indenização por dano moral na relação de consumo existente entre os usuários e as operadoras de telefonia móvel. O objetivo volta-se para a análise da efetividade do caráter pedagógico das condenações por danos morais contra as operadoras de telefonia móvel em Macapá, capital do Amapá. O procedimento metodológico estruturou-se na pesquisa bibliográfica e consulta à legislação específica voltada para o instituto do dano moral e ao Direito do Consumidor, completando-se com a análise de dados coletados junto ao Tribunal de Justiça do Amapá, referentes ao número de ações de indenização por danos morais ajuizadas nos anos de 2011 a 2013 em face das operadoras de telefonia móvel, verificando-se os respectivos resultados de mérito, bem como identificando o valor médio das condenações. Constatouse que no período analisado houve um crescimento de $6,79 \%$ no número de ações ajuizadas pleiteando indenização por danos morais contra as empresas de telefonia móvel, embora o índice de condenações tenha se mantido na média de $91,33 \%$, sendo o valor médio das indenizações fixado em torno de $\mathrm{R} \$$ 2.111,17 (dois mil cento e onze reais e dezessete centavos).

Palavras-chaves: Dano moral. Ineficácia. Pedagógica. Telefonia móvel. Macapá.

Sumário: 1 Introdução - 2 Indenização por dano moral - 3 Análise da (in)eficácia do caráter pedagógico das condenações judiciais por danos morais contra as operadoras de telefonia móvel em Macapá/ AP - 4 Considerações finais - Referências

\section{Introdução}

O presente trabalho de pesquisa resulta da seguinte problemática: em que medida o caráter pedagógico das condenações por danos morais individuais contra as operadoras de telefonia móvel na cidade de Macapá, Estado do Amapá, tem se mostrado (in)eficaz? A linha de investigação adotada apoiou-se na hipótese de 
que as condenações por danos morais nas ações individuais são majoradas em valores relativamente baixos, considerando o poder econômico das operadoras de telefonia móvel, de modo que se torna mais vantajoso para elas se sujeitarem ao pagamento de eventuais condenações judicias que efetivamente corrigir sua postura como prestadora de serviço, de modo a respeitar efetivamente os direitos dos usuários, afastando-se assim da função pedagógica das condenações.

A execução do trabalho se deu, basicamente, por meio de duas frentes de pesquisa, sendo a primeira de referência, voltada para o instituto do dano moral e, posteriormente, coleta de dados junto ao Tribunal de Justiça do Amapá quanto ao número de processos registrados em determinado período contra as empresas de telefonia móvel que atuam em Macapá, analisando o provimento final destes e valor médio das condenações.

O primeiro título será dedicado ao estudo do instituto do dano moral, perpassando pelo estudo de noções preliminares, natureza jurídica da indenização por dano moral e detalhamento de sua dúplice finalidade (compensatória e punitiva).

O segundo título ocupa-se da análise de dados coletados com a finalidade de verificar a corroboração ou descarte da hipótese levantada.

Naturalmente, o trabalho tem o condão de facilitar o conhecimento e entendimento do público em geral quanto ao instituto jurídico do dano moral, sobretudo quanto ao detalhamento de suas finalidades, sendo nesta perspectiva instrumento que contribui para uma postura mais crítica e ativa da sociedade na defesa dos seus direitos enquanto consumidores.

\section{Indenização por dano moral}

\subsection{Noções preliminares de dano moral}

A Constituição Federal de 1988, no seu Título II - que trata dos direitos e garantias fundamentais -, no artigo 5ㅇ, inciso X, arrola dentre os direitos e deveres individuais e coletivos o direito à indenização por dano moral, preceituando "que são invioláveis a intimidade, a vida privada, a honra e a imagem das pessoas, assegurado o direito à indenização pelo dano material ou moral decorrente de sua violação".

Por sua vez, na mesma linha de raciocínio, o Código Civil vigente, diferentemente do código anterior, garante expressamente o direito à indenização decorrente do dano moral, conforme inteligência do artigo 186 combinado com o artigo 927 daquele diploma legal, transcritos a seguir na íntegra:

Art. 186. Aquele que, por ação ou omissão voluntária, negligência ou imprudência, violar direito e causar dano a outrem, ainda que exclusivamente moral, comete ato ilícito. 
Art. 927. Aquele que, por ato ilícito (arts. 186 e 187), causar dano a outrem, fica obrigado a repará-lo.

O Código de Defesa do Consumidor - CDC, de igual modo, assegura o direito à indenização por dano moral causado ao consumidor, sendo inclusive tal garantia elencada entre os direitos básicos do consumidor, conforme redação do artigo 6으, inciso VI, da Lei no 8.078 de 11 de novembro de 1990, in verbis: "Art. 6o São direitos básicos do consumidor: [...] VI - a efetiva prevenção e reparação de danos patrimoniais e morais, individuais, coletivos e difusos".

Todavia, em que pese à expressa previsão legal da garantia de reparação do dano moral, nenhum diploma legal levou a cabo a delimitação, conceituação do que venha a ser dano moral, tratando-o apenas de forma diversa do dano material, de onde surge o conceito por exclusão de que seriam os danos não patrimoniais.

Registre-se que os doutrinadores não se afinam de forma uníssona na delimitação do que seria o dano moral; contudo, respeitadas as nuances individuais, já há bem definidos conceitos amplamente difundidos no meio jurídico e comungados por doutrinadores de renome, tais como Maria Helena Diniz, Sérgio Cavalieri Filho, Carlos Roberto Gonçalves, entre outros.

Nesse sentindo, Carlos Roberto Gonçalves tece a seguinte conceituação:

Dano moral é o que atinge o ofendido como pessoa, não lesando seu patrimônio. É lesão de bem que integra os direitos da personalidade, como a honra, a dignidade, a intimidade, a imagem, o bom nome, etc., como se infere dos arts. 1으, III, e 5ํ, V e X, da Constituição Federal, e que acarreta ao lesado dor, sofrimento, tristeza, vexame e humilhação (GONÇALVES, 2012, p. 379).

Maria Helena Diniz traz conceito baseado em Wilson Melo da Silva, segundo o qual "o dano moral vem a ser a lesão de interesses não patrimoniais de pessoa natural ou jurídica (CC, art. 52; Súmula no 227, STJ), provocada pelo fato lesivo" (ZANNONI, 1982 apud DINIZ, 2010, p. 90).

Sérgio Cavalieri Filho constrói um conceito mais abrangente, seguindo a mesma linha de raciocínio voltada a lesões imateriais ligadas à personalidade:

[...] em sentido estrito dono moral é violação do direito à dignidade. [...] Dano moral em sentido amplo, envolve diversos graus de violação a direitos da personalidade, abrangendo todas as ofensas à pessoa, considerada esta em suas dimensões individual e social, ainda que sua dignidade não esteja arranhada. [...] Como se vê, hoje o dano moral não mais se restringe à dor, tristeza e a sofrimento, 
estendendo sua tutela a todos os bens personalíssimos - os complexos de ordem ética -, razão pela qual podemos defini-lo, de forma abrangente, como sendo uma agressão a um bem ou atributo da personalidade (CAVALIERI FILHO, 2012, p. 88 e 90).

Notadamente, a construção conceitual formulada por Cavalieri Filho mostra-se mais abrangente e, por isso, mais adequada ao momento de evolução experimentado pelo instituto e em contemporaneidade com a ordem constitucional vigente, cujo vetor axiológico está voltado para a dignidade da pessoa humana, que assume função de viga mestra no ordenamento pátrio, sendo nesta perspectiva os seus direitos fios condutores da essência lógica do sistema, qual seja, a busca e preservação da dignidade humana.

Ademais, a aplicação do instituto do dano moral na seara consumerista do direito ou, como se diz, direito do consumidor, por si só já representou manifestação de vanguarda quando trazida expressamente pelo CDC - Lei oㅛ 8.078/90.

Rizzato Nunes, ao introduzir os estudos acerca da tutela legal dos consumidores contra os danos oriundos da relação de consumo, tece esclarecedora consideração, que, de forma lógica, exprime a essência teleológica do direito do consumidor. Assim pondera o autor:

Como decorrência de todas as garantias constitucionais, a iniciar pelo princípio maior da intangibilidade da dignidade humana, garantia da vida sadia, do piso vital mínimo, da inviolabilidade da intimidade, vida privada, honra e imagem das pessoas, do direito de ser informado e se informar, de receber produto e serviços de qualidade, a preços baixos e eficientes, de só receber publicidade verdadeira, etc., a Constituição Federal garante ao consumidor atingido direito à indenização contra as violações praticadas.

Essa proteção pode ser exercida de maneira preventiva ou, caso a violação se consume, está garantido o direito à indenização pelos danos materiais e morais causados (NUNES, 2005, p. 306).

Assim sendo, deduz-se em consequência lógica que o direito do consumidor possa garantir ao consumidor lesado a reparação dos danos sofridos, razão pela qual comporta em seu bojo o instituto do dano moral, garantindo a respectiva indenização em razão de sua ocorrência. Neste sentido, destaca Rizzato ao lecionar sobre o direito à indenização nas relações de consumo:

Todo aparato legal visa a prevenir a ocorrência de danos ao consumidor, quer estipulando obrigações ao fornecedor, quer responsabilizando-o 
por danos e defeitos, quer restringindo a autonomia da vontade nos contratos, quer criminalizando condutas, mas tal não impede que tais danos venham a ocorrer. Por isso, é assegurado como direito do consumidor o ressarcimento do prejuízo sofrido, seja patrimonial, moral, individual, coletivo ou difuso, pois, do contrário, não haverá efetividade na tutela [...] (NUNES, 2005, p. 68).

Não obstante a previsão expressa no CDC, todo microssistema deve ser interpretado de forma sincrética, posto que sua essência é a proteção do consumidor, razão pela qual em todas as relações consumeristas devem ser observados os princípios vetores do sistema, tais como transparência, boa-fé, equidade, entre outros, sendo que a mera violação desses princípios pode configurar dano ao consumidor.

Flávio Monteiro de Barros, ao introduzir os estudos a respeito do instituto do dano moral, pondera que:

$\mathrm{O}$ artigo 5ㅇ, $\mathrm{V}$ e X, da CF eliminou a celeuma sobre a reparação ou não do dano moral, ordenando expressamente a sua indenização. Posteriormente, o art. 6ㅇ, VI, do CDC, reiterou essa obrigação de indenizar o dano moral, que acabou sendo corroborada pelo art. 186 do $\mathrm{CC} / 02$.

Os detratores da obrigação de indenizar o dano moral argumentavam: a) é imoral exigir dinheiro pela perda de um ente querido ou violação de direito personalíssimo; b) é impossível mensurar o valor pecuniário da dor; c) é impossivel delimitar as pessoas que têm direito à indenização, pois a dor da perda de um ente querido acaba atingido parentes e amigos; d) é impossivel o retorno ao status quo ante; e) a função da responsabilidade civil não é punir o ofensor, mas reparar o dano por este causado.

Prevaleceu, como vimos, a corrente favorável à obrigação de indenizar, destacando-se os seguinte argumentos: a) é imoral deixar passar em branco uma ofensa; b) é ilógico não indenizar o dano moral na medida em que as pequenas ofensas materiais são indenizadas; c) a indenização dos danos morais exerce papel indutor do comportamento social adequado; d) a indenização ameniza o sofrimento; e) o direito fornece critérios de mensuração do valor da indenização (BARROS, 2007, p. 276).

Portanto, hodiernamente resta pacificado o cabimento de indenização por danos morais, inclusive de forma cumulativa com danos materiais, conforme previsão legal e entendimento sumulado do Egrégio Superior Tribunal de Justiça - STJ: 
“Súmula 37. São cumuláveis as indenizações por dano material e moral, oriundos do mesmo fato". Admite-se ainda a configuração do dano moral contra pessoa jurídica, nos termo da Súmula no 227 do STJ, que traz o seguinte enunciado: “A pessoa jurídica pode sofrer dano moral".

De fato, o instituto galgou considerável evolução e consolidação no sistema jurídico brasileiro, havendo pontos cuja evolução foi promovida pela doutrina e outros pacificados pela jurisprudência.

Contudo, o debate sobre determinados substratos desse instituto permanecem vivos, sendo predominantemente decorrentes da natureza subjetiva do dano moral, o que, por consequência, os deixa desprovidos de critério objetos que conduzam sua análise, havendo em todo caso de apreciação a influência e avaliações de impressões pessoais, tanto do julgador quanto das partes.

\subsection{Natureza jurídica da indenização por dano moral}

No âmbito das ciências jurídicas, a indagação da natureza jurídica de determinado fato, coisa ou instituto pode ser traduzida - de forma bem reducionista - na pergunta: "O que é isto para o direito?". E, no que tange à natureza jurídica da indenização por dano moral, a doutrina diverge em responder: "O que é para o direito a indenização por dano moral".

Antes de relacionar as correntes doutrinárias acerca da natureza jurídica da indenização por dano moral, registra-se que esta não é, nem de longe, um pagamento pecuniário pelo dano imaterial experimentado pelo ofendido. Assim não é pelo simples fato de que a dor, sofrimento e/ou desrespeito não têm preço, sendo impraticável a sua quantificação econômica e logicamente impossível o seu ressarcimento. Nessa linha de entendimento, posiciona-se o Desembargador Cavalieri Filho:

Em razão de sua natureza imaterial, o dano moral é insusceptível de avaliação pecuniária, podendo apenas se compensado com a obrigação pecuniária imposta ao causador do dano, sendo esta mais uma satisfação do que uma indenização (CAVALIERI FILHO, 2012, p. 90-91).

A professora Maria Helena Diniz comunga do mesmo entendimento a respeito da natureza jurídica da indenização por danos morais:

Não se paga a dor sofrida, por ser esta inindenizável, isto é, insuscetível de aferição econômica, pois seria imoral que tal sentimento 
pudesse ser tarifado em dinheiro ou traduzido em cifras de reais, de modo que a prestação pecuniária teria uma função meramente satisfatória, procurando tão somente suavizar certos males, não por sua própria natureza, mas pelas vantagens que o dinheiro poderá proporcionar, compensando até certo ponto o dano que lhe foi injustamente causado (DINIZ, 2010, p. 100).

Dessa forma, infere-se que a indenização ou reparação (termo trazido pela lei) não tem a finalidade, tampouco o condão de reparar o dano em si, mas se presta como uma compensação pelas consequências de ordem negativas experimentadas pelo ofendido em razão do dano. Seria a "substituição do prazer, que desaparece, por um novo” (CAVALIERI FILHO, 2012, p. 91).

A aludida divergência doutrinária acerca da delimitação da natureza jurídica da indenização por dano moral reside no fato de alguns doutrinadores reconhecerem a ela apenas o caráter punitivo; outros, apenas o caráter compensatório. Há ainda os que defendem o caráter misto, isto é, compensatório-punitivo. Acerca dessas variações de classificação, Flávio Tartuce elenca as três principais correntes doutrinárias e jurisprudenciais:

1ํㅡㄹ corrente: A indenização por danos morais tem o mero intuito reparatório ou compensatório, sem qualquer caráter disciplinador ou pedagógico. Essa tese entende-se superada na jurisprudência, pois a indenização deve ser encarada mais do que uma mera reparação.

2 ${ }^{\text {a }}$ corrente: A indenização tem um caráter punitivo ou disciplinador, tese adotada nos Estados Unidos da América, com o conceito de punitives damages. Essa corrente não vinha sendo bem aceita pela nossa jurisprudência, que identificava perigos na sua aplicação. Porém, nos últimos tempos, tem crescido o número de adeptos a essa teoria $[\ldots]$.

3a corrente: A indenização por dano moral está revestida de um caráter principal reparatório e um de caráter pedagógico ou disciplinador acessório, visando coibir novas condutas[...] (TARTUCE, 2013, p. 409-410).

Assim, infere-se que a indenização por danos morais, segundo a estrita previsão legal, possui caráter meramente compensatório. Em última análise, porém, em sintonia com a jurisprudência e doutrina hodierna, reconhece-se, além do caráter compensatório, um caráter punitivo, pedagógico ou desestimulador, entendimento defendido por Diniz (2010), Gonçalves (2012), Cavalieri Filho (2012), 
Tartuce (2013), entre outros doutrinadores, e amplamente aplicado pelos tribunais. A título exemplificativo, cita-se julgado Superior Tribunal de Justiça - STJ, REsp 665.425/AM, Relatora Ministra Nancy Andrighi, 3a Turma, j. 26.04.2005, DJ 16.05.2005 (BRASIL, 2005).

\subsection{Critérios de configuração e de fixação do dano moral}

Como dito alhures, um dos percalços para a evolução e consolidação da indenização por dano moral foi seu caráter eminentemente subjetivo, imaterial, uma vez que a lei não municia o magistrado de balizas objetivas que delimitem a área de afetação dos danos, bem como não confere medidas para mensurar sua extensão, mesmo porque o estabelecimento de tais marcos objetivos é totalmente incompatível com a essência do dano moral, segundo a qual somente as circunstâncias fáticas de cada caso poderão fornecer os critérios norteadores do prudente arbítrio do magistrado.

Por essa razão, a questão de "o que configura o dano moral indenizável" e "qual valor deve ser a indenização" são pontos de perene discussão na doutrina e na jurisprudência. Tal preocupação mostra-se válida e justificável, pois o manejo desregrado do instituto à margem de qualquer critério pode levá-lo a uma banalização, que a doutrina e a mídia chamam de indústria do dano moral em alusão a uma transformação do instituto em meio da aferição de lucro.

Ultrapassadas as fases da irreparabilidade do dano moral e da sua inacumulabilidade com o dano material, corremos, agora, o risco de ingressar na fase da sua industrialização, onde o aborrecimento banal ou mera sensibilidade são apresentados como dano moral, em busca de indenizações milionárias (CAVALIERI FILHO, 2012, p. 92-93).

\subsection{Dano moral indenizável}

Com efeito, é necessário que se mantenha um mínimo de maturidade e razoabilidade tanto no pleito quanto na concessão da indenização por dano moral. Para tanto, é preciso que não se afaste da sua função teleológica, que, pode-se afirmar de forma inconteste, nunca foi a aferição de lucro pelo lesado. E nessa tarefa, compete ao magistrado pautar seu julgamento na razoabilidade e prudência para, a partir de cada caso, ponderar se aquele dano é ou não indenizável com base no comportamento socialmente comum, ou seja, tendo como referência o 
homem médio, "deve tomar por paradigma o cidadão que se coloca a igual distância do homem frio, insensivel, e o homem de extrema sensibilidade" (CAVALIERI FILHO, 2012, p. 93).

Em resumo, o dano moral indenizável deve ser aquele capaz de afetar a paz interior do indivíduo, in casu, do consumidor, não o mero inconveniente resultante e corriqueiro da vida social cosmopolita como pontua Cavalieri Filho:

Só deve ser reputado como dano moral a dor, vexame, sofrimento ou humilhação que, fugindo à normalidade, interfira intensamente no comportamento psicológico do indivíduo, causando-lhe aflições, angústia e desequilíbrio em seu bem-estar. Mero dissabor, aborrecimento, mágoa, irritação ou sensibilidade exacerbada estão fora da órbita do dano moral, porquanto, além de fazerem parte da normalidade do nosso dia a dia, no trabalho, no trânsito, entre os amigos e até no ambiente familiar, tais situações não são intensas e duradouras a ponto de romper o equilíbrio psicológico do indivíduo (CAVALIERI FILHO, 2012, p. 93).

As considerações trazidas pelo autor se adéquam com perfeição à configuração do dano moral na seara da responsabilidade civil (comum subjetiva) e bem servem como norte na configuração dos danos morais na seara consumerista.

Contudo, considerando as peculiaridades do direito do consumidor, sobretudo quanto à regra de responsabilidade civil objetiva adotada pelo CDC (arts. 12, 14, 18, 19 e 20), entende-se que a constatação de sofrimento nas relações de consumo é quesito dispensável para a configuração do dano moral. Nesta linha de defesa, cita-se o Enunciado no 445 da V Jornada de Direito Civil: "445 - Art. 927: O dano moral indenizável não pressupõe necessariamente a verificação de sentimentos humanos desagradáveis como dor ou sofrimento".

\subsection{Valor da indenização}

Sendo o dano moral uma conduta que tem o condão de violar direitos ligados à personalidade do indivíduo, num campo puramente subjetivo, é impossível medir a extensão do dano sofrido. Desta forma, a análise do valor a ser fixado na indenização não advém da análise das causas do dano, mas, sim, das suas consequências.

Constituindo o dano moral uma lesão aos direitos da personalidade (art. 11 a 21 do CC), para a sua reparação não se requer a determinação de um preço para a dor ou o sofrimento, mas sim um meio 
para atenuar, em parte, as consequências do prejuízo imaterial, o que traz o conceito de lenitivo, derivado ou sucedâneo [...] Desse modo, esclareça-se que não há no dano moral uma finalidade de acréscimo patrimonial para a vítima, mas sim de compensação pelos males suportados (TARTUCE, 2013, p. 392).

Neste cenário, a doutrina e a jurisprudência procuram estabelecer critérios norteadores dessa quantificação com vistas a garantir a justiça e equidade da indenização conforme as peculiaridades do caso. Nesse sentindo, Flávio Monteiro de Barros destaca alguns critérios que se mostram salutares à observação na fixação do dano moral, quais sejam:
a) as circunstâncias do caso;
b) a gravidade do dano e sua repercussão;
c) a situação do lesante e do lesado;
d) a gravidade da culpa. [...]
e) o sofrimento da vítima;
f) a culpa concorrente da vítima [...] (BARROS, 2007, p. 270).

Maria Helena Diniz, de forma inequívoca, posiciona-se pelo não engessamento normativo da quantificação do dano moral, aduzindo que esta deve ser uma tarefa a ser mais bem desempenhada pelo julgador diante das circunstâncias do caso concreto, com a prudência que da sua atividade se espera, conforme se observa a seguir:

\begin{abstract}
Parece-nos que deverá haver uma moderação na quantificação do montante indenizatório do dano moral, sem falar na necessidade de previsão legal contendo critérios objetivos a serem seguidos pelo órgão judicante no arbitramento. Na liquidação judicial, o magistrado, tem, ante a fluidez e a subjetividade do sofrimento, o dever de apurar, com seu prudente arbítrio, os critérios a serem seguidos e o quantum debeatur, tendo por standart o homem médio na sociedade ao examinar a gravidade do fato e a dimensão do dano moral ocorrido e ao ponderar os elementos probatórios (DINIZ, 2007, p. 101).
\end{abstract}

Em síntese, na definição do quantum indenizatório, em vias práticas, o magistrado deve evitar valores simbólicos e também o locupletamento da vítima, procurar manter proporção entre as consequências do dano e o valor do montante indenizatório sem, contudo, deixar de considerar a situação econômica das partes 
e deve considerar a necessidade de adequação de conduta do causador do dano, o que, neste trabalho, se chama de efeito pedagógico da condenação. "Na avaliação do dano moral o órgão judicante deve estabelecer uma reparação equitativa, baseada na culpa do agente, na extensão do prejuízo causado e na capacidade econômica do responsável" (DINIZ, 2010, p .101).

Por fim, registra-se que o CDC veda qualquer espécie de tabelamento indenizatório para danos sofridos pelo consumidor, preceituando unicamente como parâmetro de indenização a reparação integral (art. 6o, VI). Nesta ótica, o seu valor não deve ser o resultado de um cálculo matemático-econômico, mas uma medida de justiça.

\subsection{Finalidade pedagógica da indenização por dano moral no Brasil: uma aplicação mitigada dos punitives damages}

Como demonstrado no tópico 2.2 deste trabalho, a doutrina diverge acerca da natureza jurídica da indenização por dano moral, havendo o entendimento de que lei reconhece caráter apenas compensatório e que a construção doutrinária e jurisprudencial confere um caráter pedagógico.

Em que pese à consciência de que o caráter pedagógico dessas condenações não resulta de previsão legal, mas de construção doutrinária e jurisprudencial, sabe-se que sua aplicação é uma realidade no meio jurídico pátrio, sendo minoria os defensores da não atribuição de um caráter punitivo às condenações ao pagamento de indenização por danos morais.

Nessa esteira, colaciona-se uma vez mais o posicionamento de Maria Helena Diniz, Carlos Roberto Gonçalves, Cavalieri Filho e Flavio Tartuce, doutrinadores que reconhecem expressamente a dupla finalidade da indenização por dano moral.

\footnotetext{
A reparação pecuniária do dano moral é um misto de pena e de satisfação compensatória. Não se pode negar a sua função: a) penal, constituindo uma sanção imposta ao ofensor, visando a diminuição de seu patrimônio, pela indenização paga ao ofendido, visto que o bem jurídico da pessoa - integridade física, moral e intelectual - não poderá ser violado impunemente, subtraindo-se o seu ofensor às conseqüências de seu ato por não serem reparáveis; e b) satisfatória ou compensatória, pois como o dano moral constitui um menoscabo a interesses jurídicos extrapatrimoniais, provocando sentimentos que não tem preço, a reparação visa proporcionar ao prejudicado uma satisfação que atenue a ofensa causada (DINIZ, 2010, p. 109).
} 
Tem-se prevalecido, no entanto, o entendimento de que a reparação pecuniária do dano moral tem duplo caráter: compensatório para a vítima e punitivo para o ofensor. Ao mesmo tempo que serve de lenitivo, de consolo, de uma espécie de compensação para atenuação do sofrimento havido, atua como sansão ao lesante, como fator de desestímulo, a fim de que não volte a praticar atos lesivos à personalidade de outrem. [...] 0 caráter punitivo e meramente reflexo ou indireto: o autor do dano sofrerá um desfalque patrimonial que poderá desestimular a reiteração da conduta lesiva [...] (GONÇALVES, 2012, p. 397-398).

Por outro lado, não se pode ignorar a necessidade de se impor uma pena ao causador do dano moral, para no passar impune a infração e, assim, estimular novas agressões. [...]A indenização punitiva do dano moral surge como reflexo da mudança de paradigma da responsabilidade civil e atende a dois objetivos bem definidos: (através da dissuasão) e a punição (no sentido de redistribuição) (CAVALIERI FILHO, 2012, p. 91 e 106).

A indenização por dano moral está revestida de um caráter principal reparatório e um de caráter pedagógico ou disciplinador acessório, visando coibir novas condutas. Mas esse caráter acessório somente existirá se estiver acompanhado do principal. Essa tese ainda tem prevalecido na jurisprudência nacional (TARTUCE, 2013, p. 410).

Em verdade, a dissensão que merece destaque no âmbito doutrinário não diz respeito ao reconhecimento da dupla finalidade da indenização por dano moral (compensação-punição) propriamente, mas, sim, quanto à possibilidade de estabelecimento do caráter punitivo como viés autônomo dissociado do caráter compensatório, isto é, em termos práticos, o arbitramento de um valor indenizatório com vistas a compensar o dano experimentado pela vítima e outro, independente, com fito de punir o lesante no afã de desestimulá-lo a reincidir na conduta ilícita lesiva, tal como ocorre no caso dos punitives damages.

A doutrina dos punitives damages é uma teoria norte-americana que propõe a fixação do quantum do dano moral. O juiz, além de ponderar os aspectos contidos no binômio punitivo-compensatório, deve adicionar um plus, que sirva como advertência de que a sociedade não aceita comportamento ilícito lesivo.

Os opositores da aplicação dessa teoria no Brasil argumentam que ela se mostra incompatível com o sistema constitucional vigente, vez que se constitui em verdadeira pena civil sem que, contudo, disponha de previsão legal, tampouco existam limites mínimo e máximo para sua aplicação pelo magistrado. Neste aspecto, violaria o princípio da legalidade das penas, segundo o qual "não haverá pena sem prévia cominação legal” (CF, art. 5ํ, XXXIX). 
Em linhas gerais, perfilando-se ao posicionamento dos doutrinadores retrocitados, pugna-se pela fixação da indenização por dano moral com duplo caráter - compensatório ou punitivo. Contudo, entende-se que a finalidade pedagógica deve ser considerada de forma concomitante na majoração de um montante único, ganhando, neste cenário, contornos de acessório da finalidade compensatória. A razão para tanto é simples:

O caráter sancionatório permanece ínsito na condenação ao ressarcimento ou à reparação do dano, pois acarreta a redução do patrimônio do lesante.

Não se justifica, pois, como pretende alguns, que o julgador, depois de arbitrar o montante suficiente para compensar o dano moral sofrido pela vítima (e que, indireta e automaticamente, atuará como fator de desestímulo ao ofensor), adicione-Ihe um plus a título de pena civil, inspirando-se nas punitive damages do direito norte americano (GONÇALVES, 2012, p. 401-402).

Flavio Tartuce, ao falar da dupla finalidade da indenização por dano moral, adverte: “É preciso salientar que a reparação deve estar sempre presente, sendo o caráter disciplinador de natureza meramente acessória (teoria do desestímulo mitigada)" (TARTUCE, 2013, p. 410).

Neste colóquio, registre-se a existência do Projeto de Lei no 699/2011 (antigo PL n- 6.960/2002), proposto por Regina Beatriz Tavares, que pretende incluir um novo parágrafo ao artigo 944 do Código Civil com a seguinte redação: “A reparação do dano moral deve constituir-se em compensação ao lesado e adequado desestímulo ao ofensor". Maria Helena Diniz traz em sua obra trechos da exposição de motivos sustentada por Regina Beatriz:

Em suma, a reparação do dano moral deve ter em vista possibilitar ao lesado uma satisfação compensatória e, e de outro lado, exercer função de desestímulo a novas práticas lesivas, de modo a inibir comportamentos antissociais do lesante, ou de qualquer outro membro da sociedade, traduzindo-se em montante que represente advertência ao lesante à sociedade de que não se aceita o comportamento assumido, ou o evento lesivo (DINIZ, 2010, p. 108).

Tartuce (2013), ao comentar o citado projeto de lei, afirma não vislumbrar problemas na aprovação deste, pois entende que o novo parágrafo apenas confirmaria o entendimento jurisprudencial dominante, isto é, o binômio compensaçãopunição. 
Nesse contexto, é patente o curso da consolidação doutrinária no sentido de reconhecer a finalidade pedagógica do dano moral, a despeito da previsão expressa em lei. Um importante marco nesta rota evolutiva foi o Enunciado ํㅡ 379, aprovado na IV Jornada de Direito Civil com a seguinte redação: “379 - Art. 944: 0 art. 944, caput, do Código Civil não afasta a possibilidade de se reconhecer a função punitiva ou pedagógica da responsabilidade civil”.

Por fim, cotejando-se os argumentos sustentados pela doutrina majoritária, a exemplo Caio Mario Pereira (PEREIRA apud CAVALIERI FILHO, 2012, p. 106), a indenização por dano moral possui dupla finalidade: compensatória e pedagógica. Enquanto a primeira finalidade tem por escopo a compensação à vítima pelo menoscabo experimentado, a segunda traduz-se numa punição que tem como função teleológica desestimulá-lo a praticar amiúde atos lesivos da mesma natureza. Nessa perspectiva, a finalidade pedagógica possui função inibitória concreta e abstrata: concreta na medida em que se direciona concretamente ao lesante, e abstrata por servir como advertência aos demais atores sociais que tal conduta não pode ser praticada impunimente.

Assim sendo, a finalidade pedagógica da indenização - que deve ser considerada na fixação do quantum indenizatório concomitantemente com a finalidade compensatória - ganha relevância no contexto social, sobretudo na seara consumerista, na qual os prestadores de serviço tendem a adotar postura comum para a universalidade de consumidores como decorrência do modelo capitalista, no qual imperam os contratos de adesão.

\section{Análise da (in)eficácia do caráter pedagógico das condenações judiciais por danos morais contra as operadoras de telefonia móvel em Macapá/AP}

Visando à confirmação da hipótese levantada, será feita neste título a análise dos dados estatísticos sobre telefonia celular e dos dados coletados no Tribunal de Justiça do Estado do Amapá.

\subsection{0 serviço de telefonia móvel}

Com a popularização da telefonia móvel e o consequente aumento proporcional do número de usuários, a infraestrutura do sistema tem se tornado limitada, de modo que o serviço tem sofrido considerável diminuição na qualidade. 
Ante a grande expansão do sistema, houve um aumento significativo no número de clientes que recorrem às operadoras requerendo soluções para os problemas relacionados à qualidade do serviço, cobranças indevidas, promoções, bloqueios, planos de serviços, entre outros. Neste cenário, as operadoras têm se mostrado ineficazes em dar respostas satisfatórias aos usuários, assumindo posturas negligentes que afetam a dignidade dos usuários enquanto consumidores.

A tabela a seguir mostra o ranking dos motivos das reclamações contra as operadoras de telefonia móvel junto à ANATEL no período de 2009 a 2012.

Tabela 1: ranking dos motivos das reclamações

\begin{tabular}{|l|c|c|c|c|}
\hline \multicolumn{1}{|c|}{ Motivos } & 2009 & 2010 & 2011 & 2012 \\
\hline Reparo & $37,0 \%$ & $46,3 \%$ & $52,6 \%$ & $52,8 \%$ \\
\hline Cobrança & $29,7 \%$ & $18,7 \%$ & $19,6 \%$ & $17,8 \%$ \\
\hline Instalação & $14,4 \%$ & $17,3 \%$ & $12,6 \%$ & $14,1 \%$ \\
\hline Cancelamento & $8,5 \%$ & $6,6 \%$ & $6,5 \%$ & $7,0 \%$ \\
\hline Atendimento & $4,9 \%$ & $5,4 \%$ & $3,6 \%$ & $2,4 \%$ \\
\hline Mudança de endereço & $2,9 \%$ & $2,2 \%$ & $1,9 \%$ & $2,0 \%$ \\
\hline Bloqueio & $1,0 \%$ & $1,3 \%$ & $1,3 \%$ & $1,3 \%$ \\
\hline Desbloqueio & $0,5 \%$ & $0,5 \%$ & $0,6 \%$ & $0,5 \%$ \\
\hline Outros & $0,3 \%$ & $0,5 \%$ & $0,4 \%$ & $0,7 \%$ \\
\hline Contrato de prestação de serviço & $0,4 \%$ & $0,5 \%$ & $0,4 \%$ & $0,6 \%$ \\
\hline Provedor de acesso & $0,03 \%$ & - & - & - \\
\hline Inclusão no SPC/Serasa & $0,02 \%$ & - & - & - \\
\hline Demais motivos & $0,5 \%$ & $0,6 \%$ & $0,6 \%$ & $0,8 \%$ \\
\hline Total & 200.218 & 183.557 & 218.399 & 297.877 \\
\hline
\end{tabular}

Fonte: <http://www.teleco.com.br/qscm_reclamacoes.asp> (TELECO, 2015).

As operadoras Oi, TIM, Vivo e Claro são as empresas de telefonia contra as quais mais são apresentadas reclamações junto à ANATEL, conforme quadro demonstrativo do período de 2009 a 2012. 
Tabela 2: ranking de reclamações por operadora

\begin{tabular}{|l|c|c|c|c|}
\hline \multicolumn{1}{|c|}{ Operadoras } & $\mathbf{2 0 0 9}$ & $\mathbf{2 0 1 0}$ & $\mathbf{2 0 1 1}$ & $\mathbf{2 0 1 2}$ \\
\hline Oi & 0,479 & 0,394 & 0,559 & 0,725 \\
\hline TIM & 0,361 & 0,381 & 0,512 & 0,445 \\
\hline Claro & 0,373 & 0,351 & 0,467 & 0,569 \\
\hline Vivo & 0,207 & 0,234 & 0,292 & 0,336 \\
\hline Aeiou & 0,396 & 0,328 & - & - \\
\hline CTBC & 0,212 & 0,253 & 0,258 & 0,257 \\
\hline Sercomtel & 0,142 & 0,057 & 0,075 & 0,044 \\
\hline
\end{tabular}

Fonte: ANATEL, 2011.

A situação referente à má qualidade dos serviços prestados pelas operadoras de telefonia móvel alcançou um nível tão crítico que, em julho de 2012, a ANATEL proibiu as empresas Claro, Oi e TIM de venderem novas linhas enquanto não melhorassem a qualidade dos seus serviços, incluindo desde a qualidade do sinal até a qualidade e eficiência no atendimento aos clientes.

Anatel proíbe Claro, Oi e TIM de vender chips de celular

Empresas só poderão voltar a vender chips depois de apresentar plano para melhorar o serviço. Proibição começa a valer na segundafeira (23).

A Agência Nacional de Telecomunicações (Anatel) tomou nesta quarta-feira (18) uma dura medida contra as operadoras de telefonia celular, Claro, a TIM e a Oi, e as proibiu de vender novas linhas. [...]

Para voltar a vender, as empresas têm que apresentar, em até 30 dias, um plano detalhado de melhoria da prestação de serviço. "Um plano que verse sobre três quesitos básicos: primeiro, a melhoria na rede; segundo a diminuição drástica no número de completamento de chamada; tem de fazer uma redução na questão do não-completamento de chamada; e principalmente resolver o problema mais rapidamente nos call centers das empresas. Elas precisam atender bem o cliente", fala o presidente da Anatel, Paulo Rezende (G1, 2012).

Não obstante a atuação enérgica da agência reguladora e a assunção de compromisso de melhoria por parte das empresas, é comum a veiculação na mídia de informações que dão conta que as empresas de telefonia móvel ocupam 
o topo no ranking das reclamações juntos aos órgãos de defesa do consumidor, conforme vislumbra-se na notícia extraída do site da UOL referente ao Procon-SP:

Ranking de reclamações do Procon agora é atualizado em tempo real 0 ranking online representava um total aproximado de 346 mil atendimentos, mas 26 Procons do Estado passarão a contribuir com dados, acrescentando 204 mil. Com esses 59\% a mais, haverá um número superior a 550 mil registros disponiveis para consulta.

Atualmente, empresas de comunicações são as que mais geram re-

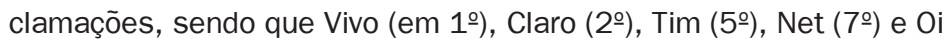
(8º) dominam o top 10. Só a primeira colocada foi alvo de 20,3 mil queixas, das quais 90,6\% foram solucionadas (UOL/OIhar Digital Edição de 02.10.2013) (UOL, 2013).

Destarte, alguns usuários, ante o desrespeito dos seus direitos consumeristas, recorrem ao judiciário buscando reparação dos danos morais sofridos, valendo-se do judiciário como última trincheira na defesa dos seus direitos.

\subsection{Método de análise de dados}

A linha de pesquisa deste trabalho foi resultante da seguinte problemática: em que medida o caráter pedagógico das condenações por danos morais individuais contra as operadoras de telefonia móvel na cidade de Macapá tem se mostrado (in)eficaz? Neste vetor investigativo, apoiou-se na seguinte hipótese: as condenações por danos morais nas ações individuais são majoradas em valores relativamente baixos, considerando o poder econômico das operadoras de telefonia móvel, de modo que se torna mais vantajoso para elas se sujeitarem ao pagamento de eventuais condenações judiciais do que efetivamente corrigir sua postura como prestadora de serviço, de modo a respeitar efetivamente os direitos dos usuários, afastando-se assim da função pedagógica das condenações.

Pois bem, para se aferir a corroboração ou descarte da hipótese levantada, serão analisados dados referentes a ações de indenização por danos morais, tramitadas no âmbito da Comarca de Macapá nos anos de 2011, 2012 e 2013 em desfavor de três operadoras de telefonia móvel que operam na capital amapaense. Foram escolhidas as operadas TIM S/A, VIVO S/A e OI S/A. A razão da escolha se deve ao fato de serem estas as operadoras mais "populares" na cidade, de onde se presume terem o maior número de clientes/consumidores. 
Os dados analisados foram fornecidos pelo Departamento de Desenvolvimento de Sistemas do Tribunal de Justiça do Amapá - DESIS/TJAP. O processo de análise foi orientado pela Secretaria de Gestão Processual Eletrônica do Tribunal de Justiça do Amapá - SGPE, desenvolvendo-se da seguinte forma:

1) Verificação do número de ações de indenização por danos morais ajuizadas em cada ano contra as três operadoras citadas.

2) Análise do número de ações julgadas em cada ano (das que foram ajuizadas).

3) Verificação do percentual de condenação nos processos julgados em cada ano.

4) Verificação da média de valor das condenações.

Com a análise descrita, pretende-se aferir se houve aumento no número de demandas judiciais contras as empresas-alvo da pesquisa no período analisado (2011, 2012 e 2013). Caso o número de condenações sofridas pelas empresas seja maior que o número de improcedências e, ainda assim, seja constatado o aumento no número de ações ajuizadas, então pode se afirmar que houve a corroboração da hipótese levantada, posto que, em que pese terem sofrido condenações por violar a dignidade do consumidor, manifestaram contumácia crescente no comportamento.

Registra-se que, para o alcance do valor médio das condenações, será feita análise por amostragem, selecionando-se aleatoriamente 145 (cento e quarenta e cinco) processos em desfavor em todo o lapso de referência.

\subsection{Demandas judiciais contra as operadoras de telefonia móvel em Macapá/AP}

No ano de 2011, foram ajuizadas 412 (quatrocentos e doze) ações de indenização por danos morais contra as operadoras de telefônica móvel selecionadas para análise neste trabalho (Vivo, TIM, Oi e Claro).

No ano de 2012, ingressaram 398 (trezentos e noventa e oito) processos pleiteando indenização por danos morais contra as mesmas empresas.

No ano em curso (2013), considerando como data-base da coleta de dados 07.11.2013, foram ajuizadas 440 (quatrocentos e quarenta) novas ações com a mesma natureza em face das empresas, conforme se observa na tabela abaixo. 
Tabela 3: número de processos ajuizados de 2011 a 2013 em Macapá/AP

\begin{tabular}{|c|c|}
\hline ANO & TOTAL \\
\hline 2011 & 412 \\
\hline 2012 & 398 \\
\hline 2013 & 440 \\
\hline TOTAL GERAL & $\mathbf{1 . 2 5 0}$ \\
\hline
\end{tabular}

Fonte: DESIS/SGPE-TJAP.

Portanto, no período de 2011 a 2013 (até o mês de novembro), foram ajuizadas na Comarca de Macapá 1.250 (mil duzentos e cinquenta) ações de indenização por danos morais contra as empresas de telefonia móvel.

A análise dos números revela que, no ano de 2012 , houve uma queda de $3 \%$ (três por cento) no número de ações ajuizadas em relação a 2011, mas que, no ano de 2013 , houve um crescimento de $11 \%$ (onze por cento) em relação ao ano anterior. Assim sendo, a variação percentual de ações pleiteando indenização por dano moral mostra um crescimento de $6,79 \%$ no período analisado. A variação pode ser visualizada no gráfico a seguir.

Gráfico 1: número de ações ajuizados - 2011/2013

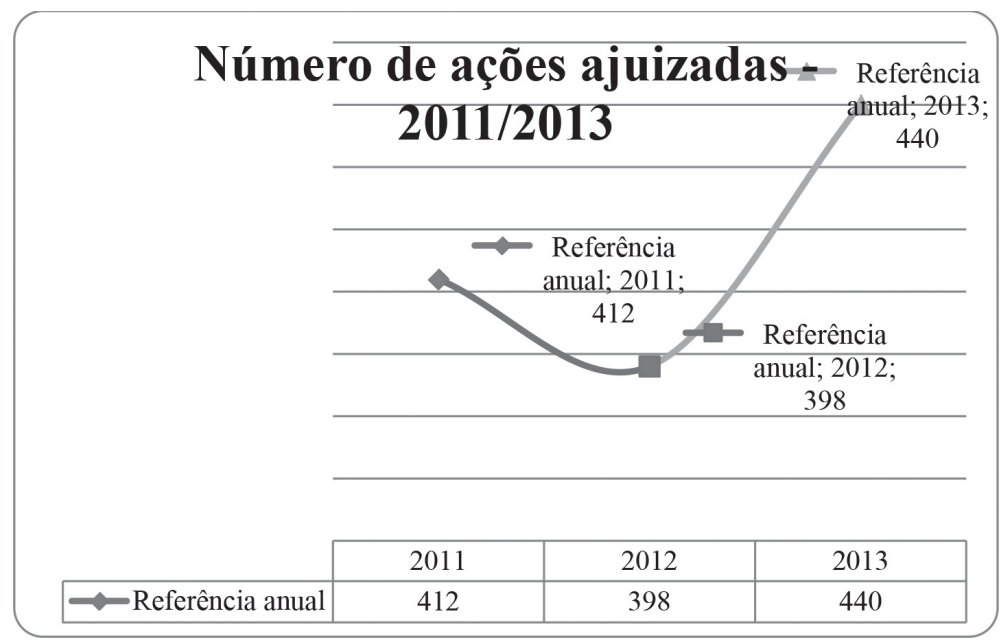

Fonte: DESIS/SGPE-TJAP. 
Nesses termos, caminha-se para a confirmação da hipótese, pois há um contínuo aumento do número de ações de indenização por danos morais ajuizadas em face das operadoras de telefonia móvel em Macapá.

\subsection{Análise das condenações sofridas pelas operadoras de telefonia móvel em Macapá}

Do total de 412 ações ajuizadas no ano de 2011, 12 (doze) ainda não foram sentenciadas. Em 160 (cento e sessenta) delas, foram homologados acordos, de modo que, em apenas 240 (duzentos) ações, o juiz adentrou de fato na análise do mérito. Das 240 (duzentos e quarenta) ações submetidas à análise de mérito pelo magistrado, 220 (duzentos e vinte) foram julgadas procedentes, e 20 (vinte), improcedentes. A seguir, gráfico dispondo em forma de porcentagem os números retrocitados.

\section{Gráfico 2: análise de ações ajuizadas em 2011 conforme o status}

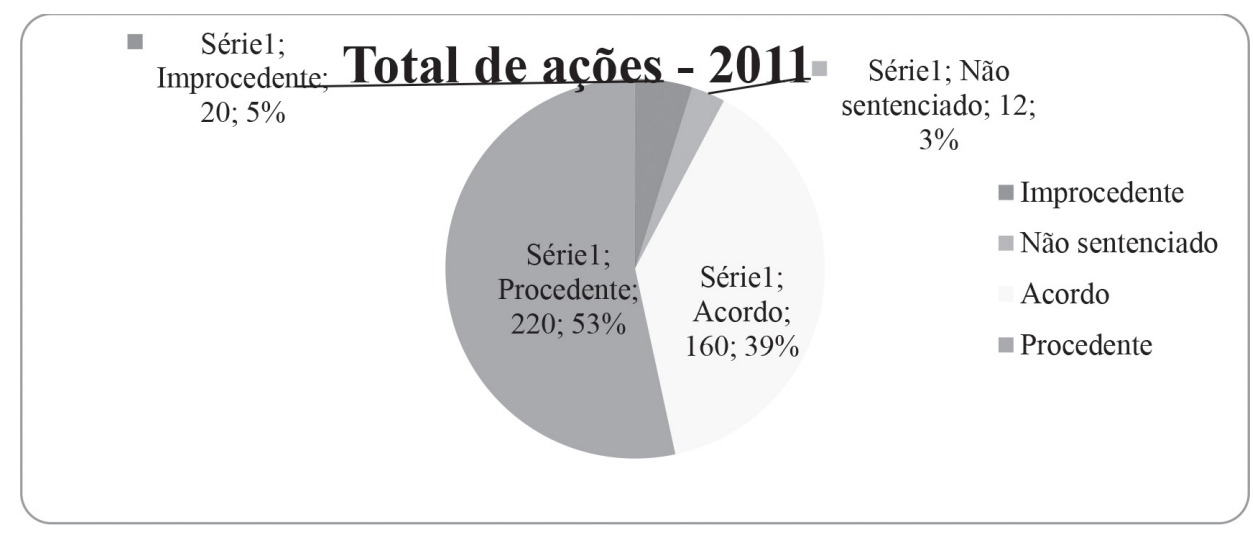

Fonte: DESIS/SGPE-TJAP.

Em 2012, ingressaram 398 (trezentos e noventa oito) ações, das quais 9 (nove) ainda não foram sentenciadas. As partes transigiram em 181 (cento e oitenta e um) processos, e 208 (duzentos e oito) lides foram decididas pelo juiz, que julgou 190 (cento e noventa) procedentes e 18 (dezoito) improcedentes. 
Gráfico 3: análise de ações ajuizadas em 2012 conforme o status

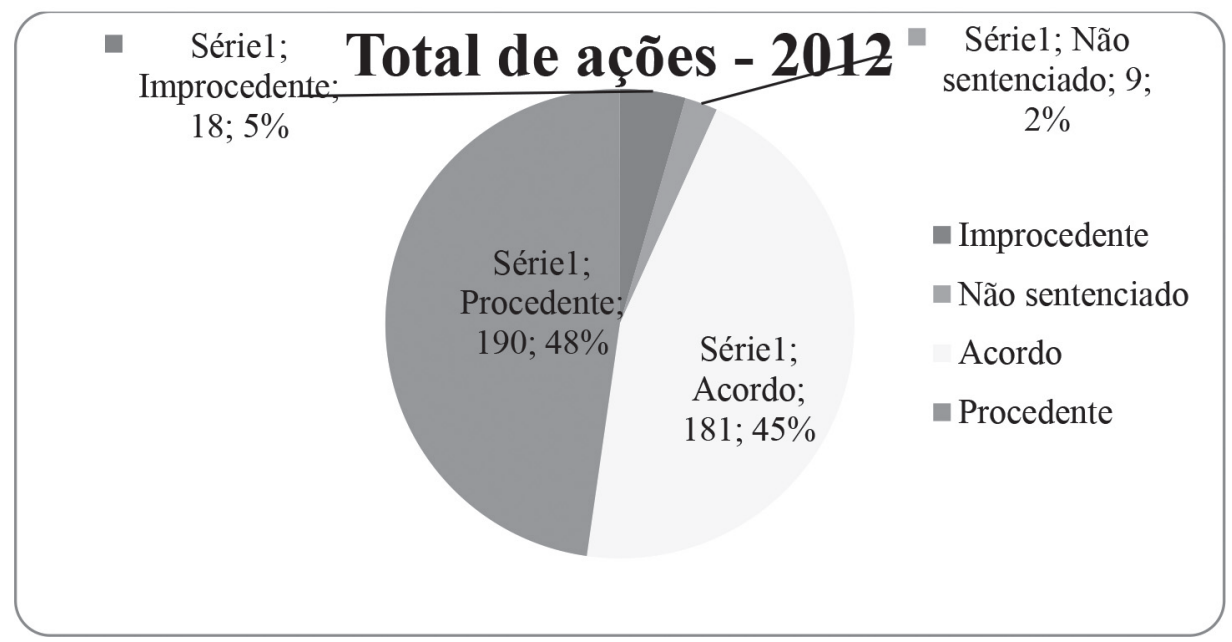

Fonte: DESIS/SGPE-TJAP.

Já em 2013, até 7 de novembro, foram distribuídas 440 (quatrocentos e quarenta) ações de indenização por danos morais contra as empresas Vivo, TIM, Oi e Claro. Desse total, 161 (cento e sessenta e um) processos ainda não foram julgados. A resolução do mérito decorreu de acordo entre as partes em 159 (cento e cinquenta e nove) casos. O magistrado pronunciou-se quanto ao mérito em 120 (cento vinte) casos, sendo pela procedência em 109 (cento) deles e, pela improcedência, em 11 (onze). 
Gráfico 4: análise de ações ajuizadas em 2013 conforme o status

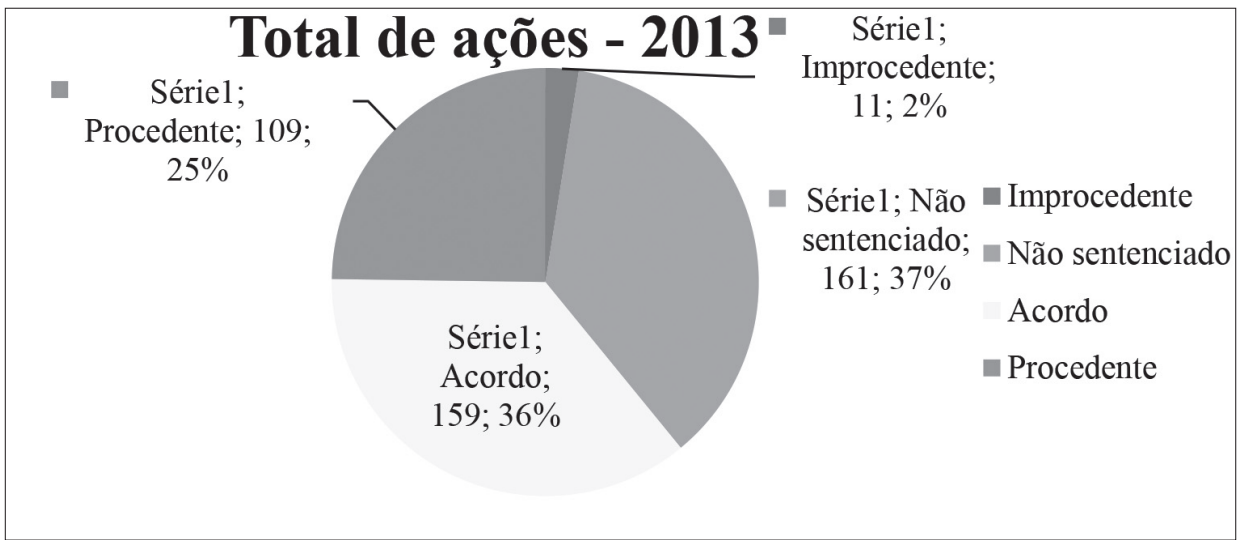

Fonte: DESIS/SGPE-TJAP.

Tabela 4: total de ações de indenização por danos morais ajuizadas por ano e com indicativo do provimento judicial

\begin{tabular}{|c|c|c|c|c|c|}
\hline Ano & Total & $\begin{array}{c}\text { Não } \\
\text { sentenciados }\end{array}$ & Acordos & Improcedentes & Procedentes \\
\hline 2011 & 412 & 12 & 160 & 20 & 220 \\
\hline 2012 & 398 & 9 & 181 & 18 & 190 \\
\hline 2013 & 440 & 161 & 159 & 11 & 109 \\
\hline
\end{tabular}

Fonte: DESIS/SGPE-TJAP.

Em todos os gráficos anteriores, é possível observar que o percentual de procedência é bem maior que o de improcedência, mesmo no ano de 2013, em que $37 \%$ (trinta e sete por cento) dos processos ainda não foram sentenciados.

Portanto, essa informação, quando comparada com o número de ações ajuizadas, contribui para corroborar a hipótese do trabalho, posto que, embora haja um índice de procedência maior que o de improcedência, o número de ações ajuizadas continua aumentando, o que faz presumir que as causas não cessaram, isto é, as condenações não atingiram a finalidade pedagógica.

Contudo, para atender o rigor científico, torna-se necessário estabelecer o percentual de condenações sofridas pelas operadoras de telefonia móvel para que, de forma precisa, seja possível responder objetivamente se houve refutação 
ou confirmação da tese levantada. Para tanto, serão considerados apenas os números de procedências e improcedências de cada ano, pois apenas nesses casos é que o magistrado decidiu o mérito conforme o seu livre convencimento motivado. Assim, não serão considerados os processos não sentenciados, nem aqueles em que houve homologação de acordo.

No ano de 2011, 240 (duzentos e quarenta) processos foram decididos com sentença de mérito, resultando em 220 (duzentos e vinte) procedências e 20 (vinte) improcedências, o que expressa um índice de procedência de $92 \%$ e de improcedência de $8 \%$, conforme gráfico abaixo.

Gráfico 5: análise de mérito das ações ajuizadas em 2011

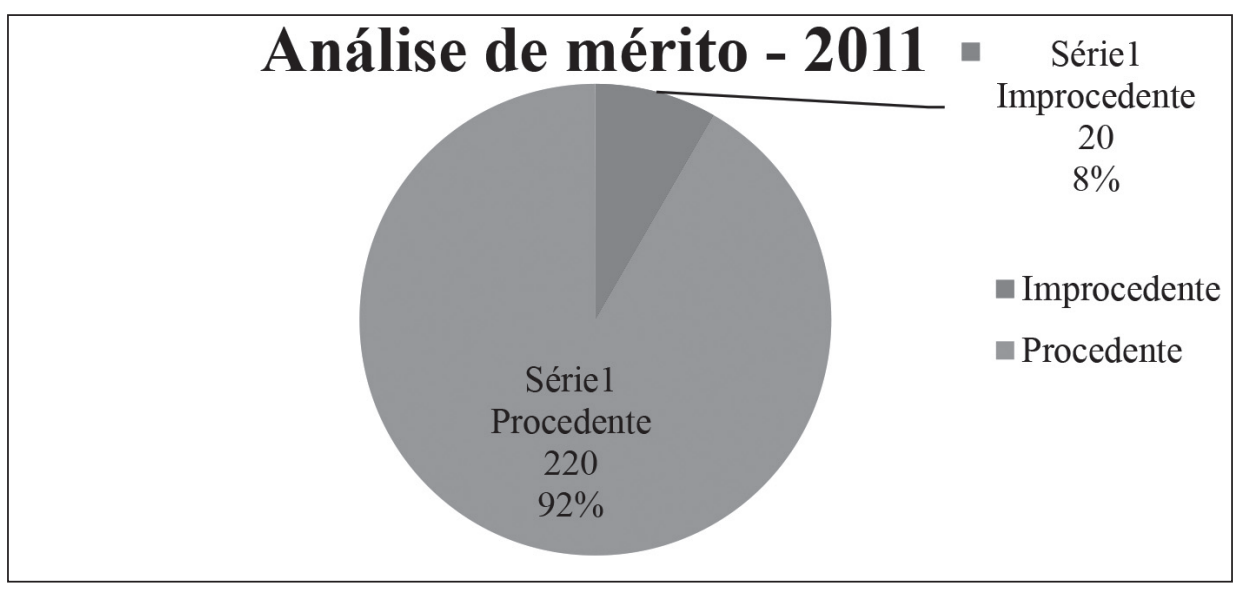

Fonte: DESIS/SGPE-TJAP.

Em 2012, houve uma redução no número de processos cuja decisão final foi proferida pelo magistrado, totalizando 208 (duzentos e oito) ações, das quais 190 (cento e noventa) foram procedentes e 18 (dezoito) improcedentes, um percentual de $91 \%$ e 9\% respectivamente, conforme ilustrado no gráfico a seguir. 
Gráfico 6: análise de mérito das ações ajuizadas em 2012

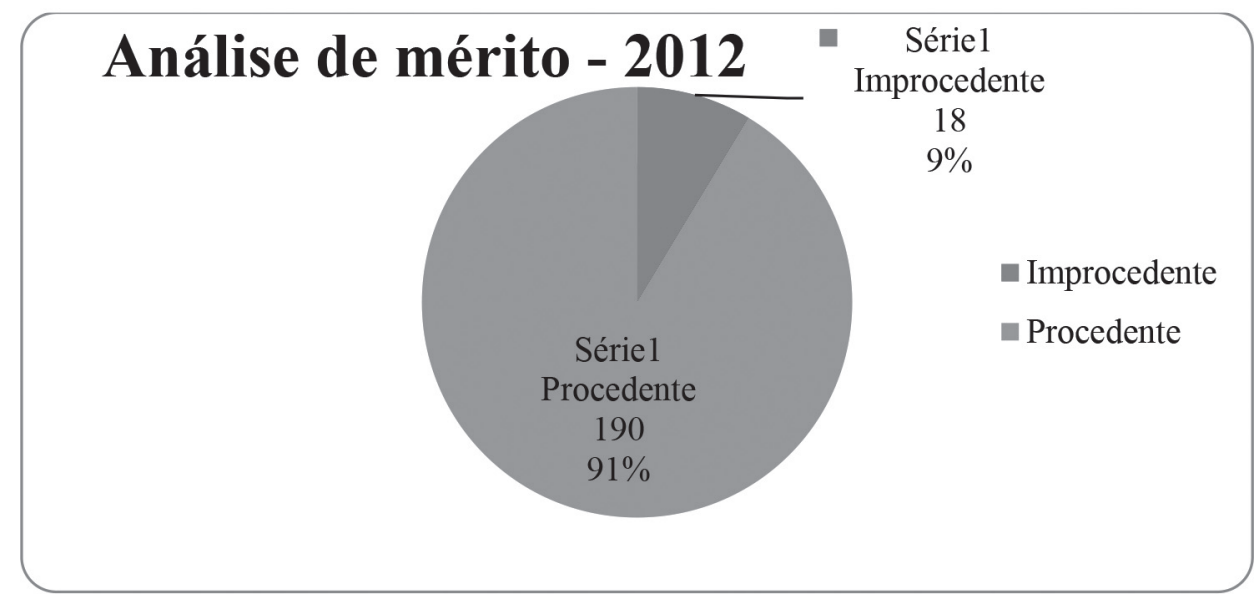

Fonte: DESIS/SGPE-TJAP.

Por fim, no ano em curso (2013), em que pese o considerável aumento no número de ações ajuizadas (440), observou-se uma redução no número de processos julgados procedentes ou improcedentes - 109 (cento e nove) e 11 (onze), totalizando 120 (cento e vinte) ações. Apesar dessa diminuição, o percentual de procedência das ações (91\%) se manteve.

Gráfico 7: análise de mérito das ações ajuizadas em 2013

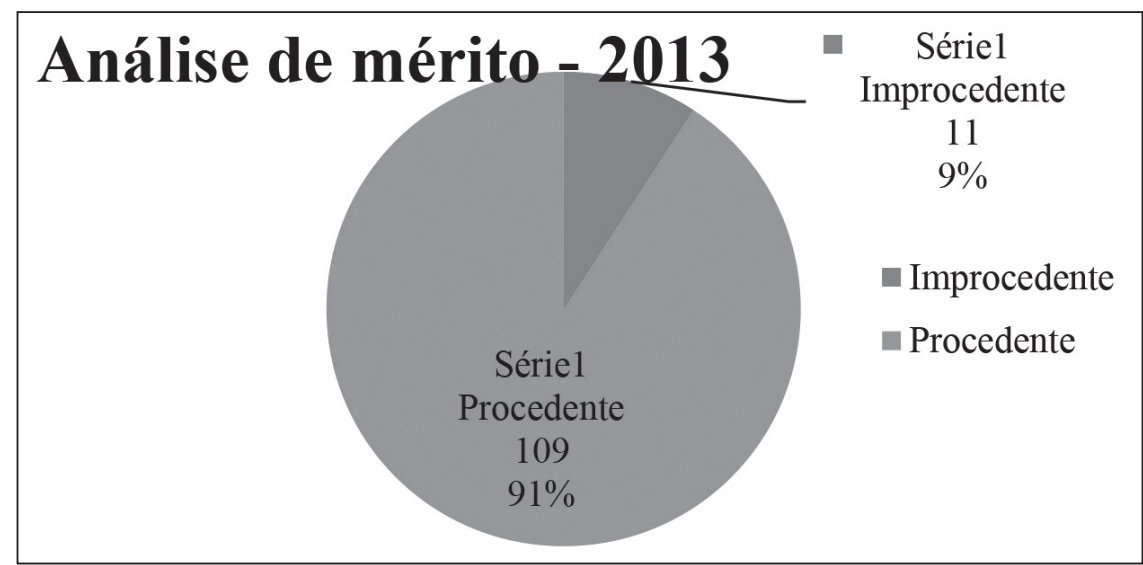

Fonte: DESIS/SGPE-TJAP. 
Então, nota-se que o índice de procedência nas ações de indenização por danos morais contra as operadoras de telefonia móvel na Comarca de Macapá se manteve constante no período analisado, com uma média de 91,33\% e desviopadrão próximo a zero, o que pode ser visualizado no gráfico abaixo.

\section{Gráfico 8: índice de condenações no período 2011/2013}

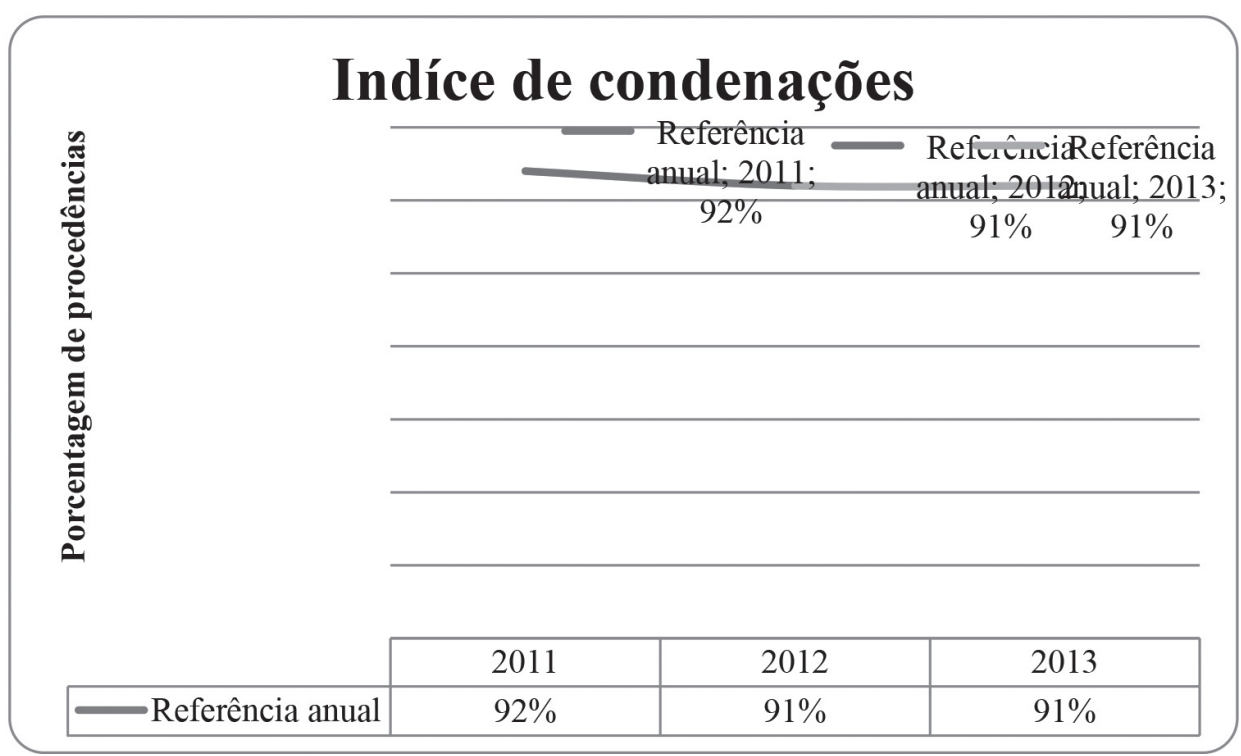

Fonte: DESIS/SGPE-TJAP.

O último ponto analisado neste tópico referente às condenações sofridas pelas empresas de telefonia móvel na cidade de Macapá trata-se de análise qualitativa referente ao estabelecimento do valor médio das condenações arbitradas. Para se obter esse valor, foram selecionadas, aleatoriamente, 145 (cento e quarenta e cinco) sentenças - quantitativo que representa pouco mais de $10 \%$ (dez por cento) do número total de ações ajuizadas no período - e anotado o valor de cada condenação para finalmente aplicar a fórmula de média do Programa Microsoft Excel [=MÉDIA(A1:A145)], alcançando o resultado de R\$2.111,17 (dois mil cento e onze reais e dezessete centavos) como valor médio das condenações (por amostragem).

Incabível aqui comentários a respeito do mérito probatório desses valores em paralelo com a hipótese central do trabalho, posto que a razoabilidade do quantum indenizatório é medida que revela grande subjetividade. Entretanto, no 
tópico seguinte, ante a necessidade de responder a hipótese do trabalho, serão feitas as ponderações baseadas nos dados objetivos coletados no curso investigativo, a partir do qual, considerando as variantes, será respondido se houve ou não a corroboração ou descarte da hipótese.

\subsection{Análise da efetividade do caráter pedagógico das condenações por danos morais contra as operadoras de telefonia móvel em Macapá}

Doravante, passa-se a responder a hipótese levantada acerca da eficácia do caráter pedagógico das condenações por danos morais contra as empresas de telefonia móvel em Macapá, desta feita com supedâneo no resultado da análise dos dados coletados.

Neste sentido, afirma-se que a hipótese levantada foi corroborada, pois, no período analisado correspondente aos anos de 2011, 2012 e 2013, embora tenha havido um índice de condenação das empresas de telefonia móvel igual a 91,33\% nas ações de indenização por danos morais, ainda assim houve um aumento de $6,79 \%$ do número de ações ajuizadas no período de referência, o que permite concluir que as causas das reclamações - violação do direito do consumidor - não cessaram, demonstrando, portanto, a ineficácia do caráter pedagógico dessas condenações, eis que não tiveram o condão de desestimular a conduta ilícita praticada pelas empresas de telefonia móvel contra seus usuários na cidade de Macapá.

No que tange a afirmação contida na hipótese de que os valores das condenações são relativamente baixos, considerando o poder econômico da operadoras de telefonia móvel - o que contribui para ineficácia do caráter pedagógico da condenação - numa análise absoluta, há que se afirmar a sua corroboração, pois o valor médio das condenações é de $\mathrm{R} \$ 2.111,17$ (dois mil cento e onze reais e dezessete centavos), o que, comparado ao faturamento das operadoras de telefonia móvel - que, só no de 2012, alcançou 90,2 bilhões de reais (TELECO, 2016) - se mostra um valor irrisório, conforme se demonstrará a seguir.

O valor médio das condenações, se multiplicado pelo número total de processos ajuizados nos três anos analisados - não se está falando em número de procedências, mas, sim, número total de processos, incluindo as improcedências - alcança o valor de $\mathrm{R} \$ 2.638 .962,50$ (dois milhões, seiscentos e trinta e oito mil novecentos e sessenta e dois reais e cinquenta centavos). Esse valor não é representativo nem mesmo quando comparado com o faturamento líquido anual de apenas uma operadora. A título de exemplo, cita-se o faturamento líquido da 
empresa Vivo S.A, que, no ano de 2012, alcançou $\mathrm{R} \$ 21.398 .000 .000,00$ (vinte e um bilhões, trezentos e noventa e oito milhões de reais) (TELECO, 2015a).

Frise-se que o cálculo acima se refere ao período total analisado, isto é, três anos. Caso o valor médio seja multiplicado pelo número total anual, a exemplo de 2013, com o maior número de ajuizamento (440) - ainda considerando as improcedências - alcança-se o valor de $\mathrm{R} \$ 928.914,80$ (novecentos e vinte e oito mil novecentos e quatorze reais e oitenta centavos). Esse valor é ínfimo quando comparado com a receita bruta anual da operadora TIM Brasil, por exemplo, que, em 2012, representou $R \$ 27.756 .000 .000,00$ (vinte e sete bilhões, setecentos e cinquenta e seis milhões reais) (TELECO, 2016a).

Portanto, considerando todos os elementos objetivos coletados na pesquisa deste trabalho, afirma-se conclusivamente que houve a confirmação da hipótese fundamental, demonstrando, assim, que a finalidade pedagógica das sentenças condenatórias por danos morais tem se mostrado ineficaz contra as empresas de telefonia móvel na cidade de Macapá.

Contudo, numa análise relativizada, há que se ponderar que este trabalho não pretende fomentar a cultura de indenizações milionárias por danos morais em sede de ações de cunho de individual, tampouco defende o tabelamento do quantum indenizatório para ações dessa natureza. Ao contrário, perfila-se ao entendimento da melhor doutrina de que o quantum é manifestação de prudência e razoabilidade do julgador, cuja delimitação objetiva só é passivel de aferição diante das circunstâncias de cada caso concreto.

Neste cenário, a variação de valores presentes nas 145 (cento e quarenta e cinco) decisões analisadas na íntegra, aliada à fundamentação de cada uma, leva a concluir que os magistrados da Comarca de Macapá, resguardadas as exceções, consideram adequadamente as circunstâncias do caso concreto na definição do quantum indenizatório e, inclusive, consideram neste valor o caráter pedagógico ou o valor de desestímulo da conduta ilícita, conforme se pode observar nos trechos de decisões a seguir colacionados, que se encontram disponíveis no site do Tribunal de Justiça do Amapá - TJAP (<www.tjap.jus.br>):

Por tudo isso, tenho que a quantia de $\mathrm{R} \$ 2.500,00$ é adequada para ressarcir os danos sofridos pela parte autora, além de servir como sanção pedagógica para que a demandada reflita sobre os sistemas de controle que impõe aos seus clientes (Processo no 000559451.2011.8.03.0001).

Destarte, entendo que o constrangimento experimentado pelo autor aliado ao poder econômico da empresa de telefonia, justifica a indenização no patamar de $\mathrm{R} \$ 10.000,00$ (dez mil reais), quantia proporcional, suficiente, para compensar os transtornos experimentados e, 
principalmente, para desestimular a ré de colocar no mercado serviço ineficiente e precário (Processo no 0021940-77.2011.8.03.0001).

Em relação ao pedido de indenização de danos morais, considerando o caráter in re ipsa do dano, o porte econômico do réu, o caráter reparatório por si da indenização e o caráter pedagógico da medida, fixo o quantum em $\mathrm{R} \$ 3.500,00$ (Processo no 0033955 78.2011.8.03.0001).

Considerando a situação havida nos autos, o porte econômico da ré e o caráter pedagógico e punitivo que dever ter a indenização, fixo o quantum em $\mathrm{R} \$ 2.000,00$. Ante o exposto, Julgo Procedente o pedido da inicial e condeno a requerida a pagar ao requerente o valor de $\mathrm{R} \$$ $2.000,00$ (dois mil reais) corrigidos com juros (Processo no 0013192 56.2011.8.03.0001).

Estabelecida a obrigação de indenizar, passo à fixação do quantum indenizatório. Para tanto, devem ser consideradas as condições sócio-econômicas da ofendida, a capacidade financeira do ofensor em arcar com a indenização, além do caráter punitivo e profilático da medida. Assim sendo, sopesando os critérios acima estabelecidos, fixo a indenização no valor de $\mathrm{R} \$ 2.000,00$ (dois mil reais), quantia que não representará para a autora uma fonte de enriquecimento sem causa, mas terá suficiente força pedagógica para que ilícitos da mesma natureza possam ser evitados no futuro (Processo no 0036233 52.2011.8.03.0001).

Em verdade, nota-se que diante da magnitude da problemática e constatada ineficácia do caráter pedagógico das condenações nas ações individuais, vislumbra-se na tutela coletiva - administrativa e judicial - maior possibilidade de efetividade do caráter pedagógico para o ajuste de conduta das operadoras de telefonia móvel aos ditames legais, hipóteses que não se analisa por escapar ao objetivo deste trabalho.

\section{Considerações finais}

O percurso investigativo por vezes envereda por rumos que não foram sequer sugestionados pelo pesquisador. Para se alcançar o descarte ou confirmação de uma hipótese, por vezes, é necessário o enfrentamento de alguns meandros, e mesmo a corroboração da tese levantada pode em si trazer surpresas ao investigador.

O curso investigativo do presente trabalho guiou-se pela hipótese de que o caráter pedagógico das condenações por danos morais é ineficaz contra as 
operadoras de telefonia móvel em Macapá, uma vez que o valor majorado nas ações individuais é relativamente baixo, considerando o poderio econômico das empresas exploradoras do serviço de telefonia móvel.

Partindo dessa premissa, adentrou-se no estudo do instituto do dano moral, no qual se verificou que, em que pese à inexistência de positivação legal, tanto a doutrina como a jurisprudência reconhecem o caráter dúplice da indenização por dano moral, sendo eles um caráter compensatório, e outro, pedagógico.

Destarte, defende a doutrina que a indenização por dano moral deve ser fixada em um valor que seja suficiente para compensar a vítima e, também, desestimular a conduta ilícita do causador do dano, numa espécie de aplicação mitigada da doutrina norte-americana do punitive damages.

Assim o é, pois, naquele caso, há a fixação do valor compensatório e, dissociado deste, a majoração de um valor, quase sempre exorbitante, como uma espécie de pena civil. Nesta perspectiva, seria possível a existência do viés punitivo, ainda que inexista a fixação do valor compensatório.

Já na forma adotada pela doutrina e jurisprudência brasileira, no cômputo do valor da indenização deve ser considerada a compensação e, também, a função pedagógica, isto é, uma exasperação que torne o valor capaz de fazer o causador do dano repensar sua conduta. De toda sorte, neste caso a função de desestímulo só existe como acessório qualificador da função compensatória, não sendo possível a fixação de uma indenização pedagógica sem a existência do caráter compensatório no caso.

Assim, em vias práticas - à luz do caráter pedagógico -, se determinado indivíduo sofre condenações em razão de uma conduta, o natural é que ele deixe de praticar tal conduta. Caso contrário, o caráter pedagógico está se mostrando ineficaz.

Valendo desse raciocínio silogístico, com base nos dados analisados no segundo título do trabalho, é possível afirmar que a hipótese nuclear foi corroborada, uma vez que, embora haja um índice de condenação igual a 91,33\% nas ações de indenização por danos morais contra as empresas de telefonia móvel, no período de três anos analisado (2011/2013), houve um aumento de 6,79\% no número de ações ajuizadas com a mesma natureza.

Contudo, embora a hipótese tenha sido corroborada, a partir da análise absoluta de dados, pondera-se que a análise das decisões, cujo valor médio de condenação é de $\mathrm{R} \$ 2.111,17$, revela que os magistrados amapaenses consideram de forma adequada o caráter pedagógico das condenações. Ocorre que o poder econômico das empresas de telefonia móvel é gigantesco, de modo que a fixação de uma indenização capaz de atingi-lo consideravelmente em sede de ação de natureza individual causaria o enriquecimento do postulante. 
Em última análise, vislumbra-se então que, diante do porte financeiro das empresas de telefonia móvel, o mais adequado para se alcançar o caráter pedagógico das condenações por danos morais seria a tutela judicial de natureza coletiva. Entretanto, considera-se válida e digna de elogio a postura de enfrentamento dos consumidores que manejam seus direitos garantidos em lei para enfrentar os desmandos praticados por fornecedores inescrupulosos. Trata-se de uma forma de manifestar a insatisfação e criar uma cultura de ativismo jurídico em represália à política do "se colar, colou", comodamente sustentada por fornecedores como as empresas exploradoras do serviço de telefonia móvel.

Recebido em: 29.02.2016.

Pareceres: 03.11.2016 e 04.11.2016.

Aprovado em: 13.12.2016.

\section{A failure of the character of educational damages for moral convictions against mobile operators in Macapá/AP}

Abstract: This paper deals with the study of the application of compensation Institute for moral damage in the existing consumption ratio among users and mobile operators. The aim turns to the analysis of the effectiveness of the pedagogical nature of convictions for moral damages against mobile operators in Macapá, Amapá capital. The methodological procedure was structured in literature and refers to specific legislation aimed at the institute for moral damages and Consumer Law, supplementing it with the analysis of data collected from the Amapá Court of Justice, referring to the number of shares compensation for moral damages filed in the years 2011-2013 in the face of mobile operators, verifying the results of merit as well as identifying the mean value of convictions. It was found that in the analyzed period there was an increase of $6.79 \%$ in the number of lawsuits filed demanding compensation for moral damages against mobile phone companies, although the conviction rate has remained at an average of $91.33 \%$, the average value of compensation set at around $\mathrm{R} \$ 2,111.17$ (two thousand one hundred and eleven reais and seventeen cents).

Keywords: Moral damage. Ineffectiveness. Pedagogical. Mobile telephony. Macapá.

Summary: 1 Introduction - $\mathbf{2}$ Compensation for moral damage - $\mathbf{3}$ Analysis (in) character of educational effectiveness of court sentences for moral damages against the mobile operators in Macapá/AP - 4 Final considerations - References

\section{Referências}

ANATEL. Ranking das prestadoras de Serviço Móvel Pessoal - SMP. 2011. Disponível em: <http://www.anatel.gov.br/Portal/verificaDocumentos/documento.asp?numeroPublicacao= 275049\&pub=principal\&filtro=1\&documentoPath=275049. pdf $>$. Acesso em: 07 nov. 2015. 
BARROS, Flávio Monteiro de. Manual de direito civil: direito das coisas e responsabilidade civil. v. 3. São Paulo: Método, 2007.

BRASIL. Lei 8.078/90, de 11 de setembro de 1990 - Dispõe sobre a proteção do consumidor e dá outras providências. Disponível em: <http://www.planalto.gov.br/ccivil_03/leis/18078. htm>. Acesso em: 17 mar. 2015.

BRASIL. Lei 9.472, de 16 de julho de 1997 - Dispõe sobre a organização dos serviços de telecomunicações, a criação e funcionamento de um órgão regulador e outros aspectos institucionais, nos termos da Emenda Constitucional no 8, de 1995. Disponível em: <http:// www.planalto.gov.br/ccivil_03/leis/19472.htm>. Acesso em: 06 nov. 2015.

BRASIL. Resolução no 477, de 7 de agosto de 2007 - Aprova o Regulamento do Serviço Móvel Pessoal - SMP. Disponível em: <http://legislacao.anatel.gov.br/resolucoes/222007/9-resolucao-477>. Acesso em: 06 nov. 2015.

BRASIL. Constituição da República Federativa do Brasil de 1988. Disponível em: <http:// www.planalto.gov.br/ccivil_03/constituicao/constituicao.htm>. Acesso em: 17 mar. 2015.

BRASIL. Superior Tribunal de Justiça - STJ, REsp 665.425/AM, Relatora Ministra Nancy Andrighi, 3a Turma, j. 26.04.2005, DJ 16.05.2005. Disponível em: <https://stj.jusbrasil. com.br/jurisprudencia/7228235/recurso-especial-resp-665425-am-2004-0068236-3/ inteiro-teor-12975070>.

CAMARA, Projeto de Lei PL 6.960/2002 - Altera o Código Civil, instituído pela Lei no 10.406, de 10 de janeiro de 2002. Disponível em: <http://www.camara.gov.br/proposicoesWeb/ prop_mostrarintegra?codteor=862095\&filename=Avulso+-PL+699/2011>. Acesso em: 28 out. 2014.

CAVALIERI FILHO, Sergio. Programa de responsabilidade civil. 10. ed. São Paulo: Atlas, 2012.

DINIZ, Maria Helena. Curso de direito civil brasileiro: responsabilidade civil. v. 7. 21.ed. rev. e atual. de acordo com a Reforma do CPC. São Paulo: Saraiva, 2007.

. Curso de direito civil brasileiro: responsabilidade civil. v. 7. 24. ed. São Paulo: Saraiva, 2010.

GONÇALVES, Carlos Roberto. Direito civil brasileiro: responsabilidade civil. v. 4. 5. ed. São Paulo: Saraiva, 2012.

G1. Anatel proíbe Claro, Oi e Tim de vender chips de celular. Disponível em: <http://g1.globo. com/jornal-da-globo/noticia/2012/07/anatel-proibe-claro-oi-e-tim-de-vender-chips-de-celular. html>. Acesso em: 06 nov. 2015.

NUNES, Luiz Antonio Rizzatto. Curso de direito do consumidor. com exercícios. 2. ed. rev., modif. e atual. São Paulo: Saraiva, 2005.

ONU. Resolução 39/248 de 16 de abril de 1985 - Defesa do Consumidor/Organização das Nações Unidas - ONU. Disponível em: <http://www.un.org/documents/ga/res/39/a39r248. htm>. Acesso em: 17 jul. 2015.

TARTUCE, Flávio. Direito Civil: direito das obrigações e responsabilidade civil. 28. ed. Rio de Janeiro: Forense; São Paulo: Método, 2013. 
TELECO. Ranking dos motivos das reclamações. Disponível em: <http://www.teleco.com. br/qscm_reclamacoes.asp>. 2015. Acesso em: 07 nov. 2015.

TELECO. Seção: Telefonia Celular - vivo. Disponível em: <http://www.teleco.com.br/ Operadoras/Vivo.asp>. 2015a. Acesso em: 07 nov. 2015.

TELECO. O Desempenho do Setor de Telecomunicações no Brasil - Séries Temporais, preparado pelo Teleco para a Telebrasil. Disponivel em: <http://www.teleco.com.br/estatis. asp. 2016>. Acesso em: 06 fev. 2016.

TELECO. Seção: Telefonia Celular - TIM. Disponível em: <http://www.teleco.com.br/ Operadoras/Tim.asp>. 2016a. Acessado em: 06 fev. 2016.

UOL. Ranking de reclamações do Procon agora é atualizado em tempo real. Disponível em: <http://olhardigital.uol.com.br/pro/noticia/38002/38002>. 2013. Acesso em: 07 nov. 2015. 